\title{
Likuiditas Saham dan Cash holding Di Indonesia
}

\author{
Bambang Sutrisno \\ Universitas Muhammadiyah Jakarta \\ bambang.febumj@gmail.com
}

\begin{abstract}
Prior studies have focused on the determinants of cash holdings. The purpose of this study is to investigate the relationship between cash holding and stock liquidity in Indonesia. This study employs panel data analysis for a sample of 115 manufacturing firms listed on the Indonesia Stock Exchange over the period from 2010 to 2014. This study considers share turnover as the proxy for the stock liquidity. The results show that stock liquidity has a positive and significant effect on cash holding. This finding is in line with Chen et al. (2012), Nyborg and Wang (2013), and Tehrani et al. (2014).
\end{abstract}

Keywords: cash holding; stock liquidity; share turnover

\begin{abstract}
Abstrak
Penelitian sebelumnya telah berfokus pada faktor penentu cash holding. Tujuan dari penelitian ini adalah menginvestigasi hubungan cash holding dan likuiditas saham di Indonesia. Penelitian ini menggunakan analisis data panel untuk sampel 115 perusahaan manufaktur yang terdaftar di Bursa Efek Indonesia selama periode 2010 sampai 2014. Penelitian ini mempertimbangkan share turnover sebagai ukuran likuiditas saham. Hasil penelitian menunjukkan bahwa likuiditas saham berpengaruh positif dan signifikan terhadap cash holding. Temuan ini sejalan dengan Chen dkk. (2012), Nyborg dan Wang (2013), serta Tehrani dkk. (2014).
\end{abstract}

Kata kunci: cash holding; likuiditas saham; share turnover

Diterima: 1 Januari 2108; Revisi: 2018; Disetujui: 2018 


\section{PENDAHULUAN}

Kas adalah aset yang paling likuid diantara aset-aset lainnya. Jumlah kas yang tersedia dapat memengaruhi likuiditas perusahaan dan mencerminkan kemampuan perusahaan memenuhi seluruh kewajibannya secara tepat waktu. Selain itu, ketersediaan kas juga dapat membantu peningkatan penjualan dan keuntungan perusahaan. Gill dan Shah (2012) mendefinisikan cash holding sebagai uang tunai di tangan atau yang siap tersedia untuk diinvestasikan pada aset fisik dan dibagikan kepada investor.

Menurut Wiyono dan Kusuma (2017), terdapat empat motif perusahaan dalam memegang kas, yaitu motif transaksi, motif berjaga-jaga, motif spekulatif, dan motif compensating balance. Motif transaksi yang dimaksudkan bahwa perusahaan membutuhkan sejumlah uang tunai membiayai kegiatannya seharihari, seperti untuk membayar gaji dan upah, membeli barang, membayar tagihan, dan pembayaran utang kepada kreditur apabila jatuh tempo. Motif berjaga-jaga dilakukan guna berjaga-jaga terhadap kebutuhan yang mungkin terjadi namun tidak jelas kapan terjadinya (misalnya kebakaran, kecelakaan). Motif spekulatif bertujuan untuk mengambil keuntungan apabila kesempatan itu ada, misalnya perusahaan menggunakan kas yang dimilikinya untuk diinvestasikan pada sekuritas (saham dan obligasi) dengan harapan setelah membeli sekuritas tersebut harganya akan meningkat. Motif compensating balance merupakan keharusan perusahaan apabila meminjam sejumlah uang dari bank. Apabila perusahaan meminjam uang di bank, umumnya bank menghendaki agar perusahaan tersebut meninggalkan sejumlah uang di rekeningnya.

Mempelajari faktor-faktor yang memengaruhi keputusan cash holding dapat membantu manajer keuangan membuat penyesuaian kebutuhan tingkas pemegangan kas dan mencapai tingkat sasaran. Studi empiris sebelumnya mengenai cash holding lebih fokus pada faktor penentu cash holding, khususnya di Indonesia. Sedikit sekali penelitian yang menguji cash holding dari perspektif lain. Sutrisno dan Gumanti (2016) mencoba menguji pengaruh krisis keuangan global dan karakteristik perusahaan terhadap cash holding perusahaan di Indonesia. Mereka menemukan bahwa perusahaan-perusahaan di Indonesia memegang kas 
lebih banyak pada saat krisis keuangan global dibandingkan pada saat periode normal. Set kesempatan investasi dan pembayaran dividen berpengaruh positif terhadap cash holding, sedangkan ukuran perusahaan, capital expenditure, pengganti aset likuid, dan leverage berpengaruh negatif terhadap cash holding. Penelitian lainnya adalah Sutrisno (2017) yang menginvestigasi secara empiris hubungan antara cash holding dan nilai perusahaan. Hasil penelitian menyimpulkan bahwa terdapat hubungan linear antara cash holding dan nilai perusahaan. Hubungan kuadratik antara cash holding dan nilai perusahaan tidak ditemukan. Hasil penelitian tersebut mendukung pecking order theory.

Terdapat tiga teori yang dapat membantu menjelaskan karakteristik perusahaan mana yang memengaruhi keputusan cash holding. Pertama, teori trade-off yang menyatakan bahwa perusahaan mengidentifikasi tingkat cash holding optimal dengan membobot biaya dan keuntungan marjinal memegang kas (Ferreira dan Vilela, 2004). Kedua, teori pecking order dari Myers (1984), yang didukung oleh landasan teori Myers dan Majluf (1984), menyatakan bahwa untuk meminimalkan biaya asimetri informasi dan biaya pendanaan lainnya, perusahaan sebaiknya mendanai investasi terlebih dahulu menggunakan laba ditahan, kemudian dengan utang yang aman dan utang berisiko, serta terakhir dengan ekuitas. Teori ini menunjukkan bahwa perusahaan tidak memiliki tingkat kas sasaran, namun kas digunakan sebagai penyangga (buffer) antara laba ditahan dan kebutuhan investasi (Ferreira dan Vilela, 2004). Teori yang ketiga adalah teori arus kas bebas (free cash flow theory) dari Jensen (1986) yang mengemukakan bahwa manajer memiliki insentif untuk menciptakan kas guna meningkatkan jumlah aset di bawah kontrol mereka dan memperoleh kekuatan diskresioner atas keputusan investasi perusahaan. Kas mengurangi tekanan untuk bekerja dengan baik dan memungkinkan manajer berinvestasi pada proyek-proyek yang sesuai kepentingan mereka, namun bukan untuk kepentingan pemegang saham (Ferreira dan Vilela, 2004).

Determinan cash holding yang digunakan sebagai variabel kontrol dalam penelitian ini adalah sebagai berikut: 
Perusahaan yang lebih menguntungkan (profitable) umumnya memiliki lebih banyak arus kas. Perusahaan tersebut enggan memegang kas dalam jumlah besar. Di sisi lain, kreditur cenderung meminjamkan uang kepada perusahaan yang lebih menguntungkan karena lebih sedikit berisiko. Konsisten dengan teori tradeoff, terdapat hubungan negatif antara profitabilitas dan cash holding.

Berdasarkan teori pecking order, dana internal merupakan opsi pertama untuk pendanaan. Perusahaan yang lebih menguntungkan yang memiliki arus kas tinggi mencoba untuk mengakumulasi kas lebih banyak. Selain itu, manajer dalam situasi ini memiliki fleksibilitas yang lebih tinggi dalam kebijakan keuangan dan pada gilirannya perusahaan semacam itu akan memegang kas lebih banyak.

Biaya yang timbul akibat kekurangan kas akan lebih tinggi untuk perusahaan dengan set kesempatan investasi yang lebih besar karena kerugian yang diharapkan berasal dari pelepasan kesempatan investasi yang berharga. Selain itu, set kesempatan investasi yang besar menciptakan permintaan sejumlah kas yang besar. karena kekurangan kas menyiratkan bahwa apabila perusahaan menggunakan pembiayaan eksternal yang mahal, hal itu harus mengorbankan kesempatan investasi yang menguntungkan. Oleh karena itu, terdapat hubungan positif antara set kesempatan investasi dan cash holding (Ferreira dan Vilela, 2004).

Teori trade-off menunjukkan adanya hubungan negatif antara ukuran perusahaan dan cash holding. Perusahaan besar umumnya lebih terdiversifikasi, kekurangan kas di satu segmen dapat dengan mudah diselesaikan melalui realokasi arus kas dari segmen lain atau melikuidasi aset pada segmen yang bukan inti (Titman dan Wessels, 1988; Opler dkk., 1999). Selain itu, perusahaan besar biasanya berada di industri untuk periode yang lebih lama, dengan ukuran mereka sendiri merupakan hasil dari pertumbuhan yang berkesinambungan selama beberapa tahun terakhir. Karakteristik yang berhubungan dengan perusahaan besar, seperti profitabilitas yang lebih tinggi, tata kelola perusahaan yang lebih baik, asimetri informasi yang lebih rendah, dan kemungkinan kesulitan keuangan dan kebangkrutan yang lebih rendah, membuat perusahaan besar lebih tertarik kepada penyedia keuangan eksternal (Brennan dan Hughes, 1991). 
Secara keseluruhan, biaya pendanaan eksternal bagi perusahaan besar yang rendah, akses yang besar untuk pasar keuangan internal, kemungkinan kesulitas keuangan dan kebangkrutan yang rendah, dan kendala keuangan yang rendah menyebabkan perusahaan besar mengakumulasi kas lebih rendah. Teori pecking order mengemukakan bahwa perusahaan besar umumnya menjaga cadangan kas yang banyak dan bahwa ukuran perusahaan adalah indikator yang baik untuk kesuksesan bisnisnya (Tehrani, 2014).

Menurut teori trade-off, secara umum diterima bahwa leverage meningkatkan probabilitas kebangkrutan. Untuk mengurangi kemungkinan mengalami kesulitan keuangan, perusahaan dengan leverage lebih tinggi diharapkan memegang kas lebih besar. Di sisi lain, sejauh rasio leverage bertindak sebagai proksi untuk kemampuan perusahaan menerbitkan utang maka perusahaan dengan leverage lebih tinggi (kemampuan yang lebih tinggi meningkatkan utang) diharapkan memegang kas lebih kecil. Dengan demikian, terdapat hubungan antara leverage dan cash holding bersifat ambigu.

Dalam teori pecking order, utang umumnya meningkat saat investasi melebihi laba ditahan dan menurun saat investasi kurang dari laba ditahan. Akibatnya, cash holding menurun ketika investasi melebihi laba ditahan dan meningkat ketika investasi kurang dari laba ditahan. Hubungan antara cash holding, utang, dan investasi menunjukkan bahwa terdapat hubungan negatif antara leverage dan cash holding.

Menurut teori arus kas bebas dari Jensen (1986), perusahaan dengan leverage rendah kurang tunduk pada pengawasan, memungkinkan manajemen mengumpulkan kas. Dengan demikian, perusahaan dengan leverage lebih kecil memegang kas lebih banyak (Ferreira dan Vilela, 2004).

Terdapat dua pandangan yang bertentangan terkait hubungan antara likuiditas saham dan cash holding. Satu pandangan mendukung hubungan positif antara keduanya dan satu pandangan lagi menyatakan hubungan negatif antara keduanya. Menurut pandangan yang menyatakan hubungan positif antara likuiditas saham dan cash holding, saham dengan likuiditas tinggi mengindikasikan 
kemampuan manajemen dalam menciptakan nilai perusahaan dan meningkatkan kesejahteraan pemegang saham, memperoleh tingkat pengembalian maksimum dengan risiko minimum, keberlanjutan dan peramalan prospek yang jelas untuk masa depan perusahaan. Perusahaan ini memiliki berbagai kesempatan investasi sehingga diharapkan memegang kas lebih banyak guna memanfaatkan kesempatan tersebut. Di sisi lain, Subrahmanyam dan Titman (2001) dan Khanna dan Sonti (2004) menunjukkan bahwa likuiditas berpengaruh positif terhadap kinerja perusahaan bahkan ketika tidak ada konflik keagenan. Fang dkk. (2009) juga menemukan bahwa perusahaan dengan saham likuid memiliki kinerja lebih baik. Kinerja yang lebih baik dapat berdampak pada pertumbuhan arus kas. Oleh karena itu, penelitian ini mengharapkan adanya hubungan positif antara likuiditas saham dan cash holding.

Pandangan yang menyatakan bahwa likuiditas saham dan cash holding memiliki hubungan negatif berasal dari dua penelitian. Penelitian pertama menyoroti peran likuiditas dalam memengaruhi kendala keuangan. Butler, dkk. (2005) menemukan bahwa perusahaan dengan saham yang lebih likuid membayar biaya lebih rendah secara substansial terhadap pendanaan eksternal. Dalam penelitian yang kedua, Almeida dkk. (2004) mendokumentasikan bahwa perusaahaan yang berkendala keuangan menunjukkan sensitivitas arus kas positif secara signifikan sedangkan perusahaan yang tidak berkendala keuangan tidak menunjukkan hubungan tersebut.

Faulkender dan Wang (2006) berpendapat bahwa perusahaan yang berkendala keuangan menghadapi biaya yang lebih tinggi untuk meningkatkan modal eksternal. Tingkat penahanan kas memungkin perusahaan yang berkendala keuangan menghindari biaya yang lebih tinggi untuk meningkatkan dana eksternal dan karenanya penahanan kas menjadi lebih berharga. Secara empiris mereka menemukan bahwa nilai kas lebih tinggi untuk perusahaan berkendala keuangan daripada perusahaan yang tidak berkendala keuangan. Denis dan Sibilkov (2010) menemukan bahwa kas lebih berharga untuk perusahaan yang berkendala keuangan karena kas memungkinkan perusahaan mengambil proyek-proyek yang meningkatkan nilai perusahaan yang mungkin mereka lewatkan. Secara 
keseluruhan, temuan dari dua penelitian tersebut menunjukkan adanya hubungan negatif antara likuiditas saham dan cash holding.

Penelitian ini mencoba menginvestigasi lebih lanjut akan hubungan antara likuiditas saham dan cash holding. Penelitian ini bertujuan untuk menguji pengaruh likuiditas saham terhadap cash holding pada perusahaan manufaktur yang terdaftar di Bursa Efek Indonesia tahun 2010-2014. Hasil penelitian menemukan bahwa likuiditas saham berpengaruh positif dan signifikan terhadap cash holding.

\section{METODE}

Penelitian ini mengobservasi saham-saham yang termasuk dalam kelompok industri manufaktur tahun 2010-2014. Pengambilan sampel dipilih berdasarkan kriteria berikut: Pertama, perusahaan manufaktur yang terdaftar secara terusmenerus di Bursa Efek Indonesia pada tahun 2010-2014. Kedua, memiliki data yang lengkap selama periode penelitian. Ketiga, memiliki ekuitas positif. Sampel akhir dalam penelitian ini sebanyak 115 perusahaan manufaktur.

Penelitian ini menggunakan data berbasis tahunan yang meliputi kas dan setara kas, total aset, total utang, total ekuitas, harga saham penutupan, jumlah saham beredar, jumlah saham yang diperdagangkan, dan laba bersih setelah pajak selama tahun 2010-2014. Data-data tersebut diperoleh dari website www.idx.co.id dan www.finance.yahoo.com.

Variabel dependen dalam penelitian ini adalah cash holding. Variabel independen yang digunakan adalah share turnover sebagai ukuran likuiditas saham. Penelitian ini juga memasukkan variabel kontrol, yang meliputi profitabilitas, set kesempatan investasi, ukuran perusahaan, dan leverage. Deskripsi variabel penelitian diringkas pada Tabel 1.

Untuk menjawab tujuan dari penelitian ini yaitu untuk menganalisis pengaruh likuiditas saham terhadap cash holding di Indonesia akan dipergunakan regresi panel. Adapun model penelitian yang digunakan dalam penelitian ini adalah:

$$
C A S H_{i t}=\beta_{0}+\beta_{1} T U R N_{i t}+\beta_{2} R O E_{i t}+T O B I N_{i t}+S I Z E_{i t}+L E V_{i t}+\varepsilon_{i t}
$$


dimana $\mathrm{CASH}_{\text {it }}$ adalah cash holding perusahaan $i$ pada tahun $t, T U R N_{i t}$ adalah share turnover perusahaan $i$ pada tahun $t, R O E_{i t}$ adalah return on equity perusahaan $i$ pada tahun $t, T O B I N_{i t}$ adalah Tobin's Q perusahaan $i$ pada tahun $t$, $S I Z E_{i t}$ adalah ukuran perusahaan $i$ pada tahun $t, L E V_{i t}$ adalah tingkat leverage perusahaan $i$ pada tahun $t$, dan $\varepsilon_{i t}$ adalah error term.

Tabel 1 Deskripsi Variabel Penelitian

\begin{tabular}{lll}
\hline \multicolumn{1}{c}{ Variabel } & \multicolumn{1}{c}{ Definisi } & \multicolumn{1}{c}{ Pengukuran Variabel } \\
\hline CASH & Cash holding & Kas dan setara kas dibagi total aset \\
& & Jumlah saham yang diperdagangkan dibagi \\
TURN & Share turnover & jumlah saham beredar \\
ROE & Return on equity & Laba bersih setelah pajak dibagi total ekuitas \\
& & Nilai buku utang ditambah nilai pasar ekuitas \\
TOBIN & Tobin's $Q$ & dibagi total aset \\
SIZE & Ukuran perusahaan & Logaritma natural dari total aset \\
LEV & Leverage ratio & Total utang dibagi total aset \\
\hline
\end{tabular}

Sebelum melakukan regresi panel, pemilihan metode estimasi terbaik perlu dilakukan terlebih dahulu. Uji Chow dan Hausman perlu dilakukan untuk menentukan metode estimasi terbaik yang nantinya akan digunakan dalam analisis, apakah model pooled ordinary least square (PLS), model efek tetap (fixed effect), atau model efek random (random effect) (Nachrowi dan Usman, 2006). Uji Chow bertujuan untuk memilih antara model PLS dengan model efek tetap. Apabila nilai uji Chow signifikan, maka model efek tetap lebih baik dibandingkan dengan model PLS. Sedangkan uji Hausman bertujuan untuk memilih antara model efek tetap dengan model efek acak. Apabila nilai uji Hausman signifikan, maka model efek tetap lebih baik dibandingkan dengan model efek acak.

\section{HASIL DAN PEMBAHASAN}

Ringkasan statistik deskriptif dari 115 perusahaan (575 observasi) yang diteliti ditampilkan pada Tabel 2. Rata-rata cash holding adalah 10,43\% untuk 
perusahaan manufaktur di Indonesia pada periode 2010-2014. Nilai tersebut lebih rendah apabila dibandingkan dengan nilai rata-rata cash holding yang didokumentasikan oleh Tehrani dkk. (2014) sebesar 24,25\% untuk sampel perusahaan terbuka di Bursa Efek Iran. Hal ini mengisyaratkan bahwa proporsi kas dan setara kas sebesar 10,43\% dari total aset perusahaan manufaktur di Indonesia.

Rata-rata share turnover sebesar 0,2342, yang menunjukkan bahwa ratarata jumlah saham yang diperdagangkan sebesar $23,42 \%$ dari jumlah saham yang beredar di pasar. Rata-rata ROE sebesar 18,1281, yang mengindikasikan bahwa rata-rata laba bersih setelah pajak sebesar 18,1281 kali total ekuitasnya. Rata-rata set kesempatan investasi yang diproksikan dengan Tobin's Q memiliki nilai lebih besar dari satu. Rata-rata total aset perusahaan manufaktur di Indonesia sebesar Rp 6,07 miliar. Rata-rata tingkat leverage adalah sebesar 14,7\%, artinya rata-rata total utang perusahaan sebesar $14,7 \%$ dari total asetnya.

Tabel 2 Ringkasan Statistik Deskriptif

\begin{tabular}{lrlrr}
\hline \multicolumn{1}{c}{ Variabel } & \multicolumn{1}{c}{ Mean } & \multicolumn{1}{l}{ Min } & \multicolumn{1}{c}{ Max } & \multicolumn{1}{c}{ Std. Dev. } \\
\hline CASH & 0,1043 & 0,0000 & 0,4831 & 0,1073 \\
TURN & 0,2342 & 0,0011 & 2,5472 & 0,3225 \\
ROE & 18,1281 & 0,5621 & 323,6014 & 23,7582 \\
TOBIN & 1,1354 & 0,4361 & 5,1432 & 0,4524 \\
SIZE (Rp miliar) & 6,0660 & 0,0132 & 233,1381 & 16,6703 \\
LEV & 0,1470 & 0,0021 & 1,5223 & 0,2034 \\
\hline
\end{tabular}

Tabel 3 menampilkan hasil uji korelasi antar variabel penelitian. Tidak terdapat korelasi antar variabel penelitian yang lebih besar dari 0,8. Oleh karena itu, dapat disimpulkan bahwa tidak terdapat multikolinearitas dalam data penelitian.

Terdapat tiga metode estimasi yang dapat dipilih dalam analisis regresi panel yaitu pooled ordinary least square (PLS), model efek tetap (fixed effect), dan model efek random (random effect). Tabel 4 menyajikan hasil uji Chow dan 
Hausman untuk menentukan metode estimasi terbaik yang akan digunakan dalam penelitian.

Tabel 3 Hasil Uji Korelasi

\begin{tabular}{lcccccc}
\hline & CASH & TURN & ROE & TOBIN & SIZE & LEV \\
\hline CASH & 1,0000 & & & & & \\
TURN & $-0,0050$ & 1,0000 & & & & \\
ROE & 0,1201 & $-0,0680$ & 1,0000 & & & \\
TOBIN & 0,0035 & $-0,0165$ & 0,2213 & 1,0000 & & \\
SIZE & 0,5437 & $-0,1740$ & 0,0435 & $-0,0427$ & 1,0000 & \\
LEV & $-0,2175$ & 0,0431 & $-0,0652$ & $-0,1853$ & $-0,0328$ & 1,0000 \\
\hline
\end{tabular}

Tabel 4 memperlihatkan bahwa hasil uji Chow dan Hausman menghasilkan p-value sebesar 0,0000. Artinya, hasil uji dari kedua tes signifikan. Dengan kata lain, hipotesis nol dari uji Chow dan Hausman ditolak. Dengan demikian, metode estimasi terbaik yang digunakan dalam penelitian ini adalah model efek tetap.

Tabel 4. Hasil Uji Chow dan Hausman

\begin{tabular}{lcc}
\hline \multicolumn{1}{c}{ Pemilihan Metode Estimasi Terbaik } & Prob. & Kesimpulan \\
\hline Uji Chow & 0,0000 & Model Efek Tetap \\
Uji Hausman & 0,0000 & Model Efek Tetap \\
\hline
\end{tabular}

Hasil regresi panel dengan model efek tetap disajikan dalam Tabel 5. Koefisien share turnover bernilai positif dan signifikan secara statistik pada tingkat $\alpha=5 \%$. Likuiditas saham berpengaruh positif dan signifikan terhadap cash holding. Artinya, semakin likuid saham suatu perusahaan maka perusahaan akan cenderung memegang kas lebih banyak. Temuan ini konsisten dengan Chen dkk. (2012), Nyborg dan Wang (2013), serta Tehrani dkk. (2014). Saham dengan likuiditas tinggi mengindikasikan kemampuan manajemen dalam menciptakan nilai perusahaan dan meningkatkan kesejahteraan pemegang saham, memperoleh tingkat pengembalian maksimum dengan risiko minimum, keberlanjutan dan peramalan prospek yang jelas untuk masa depan perusahaan. Perusahaan dengan 
saham likuid memiliki berbagai kesempatan investasi sehingga diharapkan memegang kas lebih banyak guna memanfaatkan kesempatan tersebut.

Untuk variabel kontrol, Tobin's Q memiliki koefisien negatif dan signifikan pada tingkat $\alpha=5 \%$. Ukuran perusahaan berpengaruh positif dan signifikan pada tingkat $\alpha=1 \%$. Return on equity dan tingkat leverage tidak menunjukkan pengaruh yang signifikan.

Nilai $\mathrm{R}^{2}$ sebesar $41,63 \%$ menunjukkan bahwa sebesar $41,63 \%$ variasi cash holding dapat dijelaskan oleh model penelitian. Sedangkan sisanya sebesar 58,37\% dijelaskan oleh variabel lain di luar model penelitian. Hasil penelitian menunjukkan bahwa share turnover, return on equity, Tobin's $Q$, ukuran perusahaan, dan leverage secara bersama-sama berpengaruh signifikan terhadap cash holding. Hal ini ditunjukkan dengan nilai Prob (F-stat) yang signifikan pada tingkat $\alpha=1 \%$.

Tabel 5 Hasil Regresi Panel dengan Model Efek Tetap

\begin{tabular}{lrr}
\hline \multicolumn{1}{c}{ Variabel } & Koefisien & p-value \\
\hline TURN & 0,0652 & 0,0233 \\
ROE & 0,0003 & 0,2564 \\
TOBIN & $-0,0318$ & 0,0365 \\
SIZE & 0,4271 & 0,0000 \\
LEV & 0,1623 & 0,3450 \\
\hline N & 575 & \\
R & 0,4163 & \\
F-stat & 28,3256 & \\
Prob (F-stat) & 0,0000 & \\
\hline
\end{tabular}

\section{SIMPULAN}

Penelitian ini menguji secara empiris akan hubungan antara likuiditas saham dan cash holding pada perusahaan manufaktur yang terdaftar di Bursa Efek Indonesia pada tahun 2010-2014. Hasil penelitian menunjukkan bahwa likuiditas saham berpengaruh positif dan signifikan terhadap cash holding. Perusahaan yang 
memiliki saham semakin likuid berdampak pada tingkat pemegangan kas yang semakin besar pula.

Hasil penelitian ini memberikan saran kepada investor untuk memperhatikan aspek likuiditas saham dalam pengambilan keputusan untuk berinvestasi karena perusahaan dengan saham yang semakin likuid cenderung memegang kas yang lebih besar guna memanfaatkan peluang investasi yang ada. Terdapat beberapa rekomendasi yang dapat dijadikan pertimbangan untuk penelitian sejenis di periode mendatang. Pertama, penelitian mendatang dapat menggunakan proksi likuiditas saham yang lain, seperti trading probability atau Amihud Illiquidity guna melihat konsistensi hasil penelitian dengan proksi yang berbeda. Kedua, penelitian selanjutnya dapat menggunakan variabel kontrol yang lain, seperti dividend payout ratio, struktur kepemilikan, dan lain-lain.

\section{PUSTAKA ACUAN}

Almeida, Heitor, Murillo Campello, dan Michael S. Weisbach. 2004. The Cash Flow Sensitivity of Cash. Journal of Finance, Vol. 59, No. 4: 1777-1804.

Brennan, Michael dan Patricia J. Hughes. 1991. Stock Prices and the Supply of Information. Journal of Finance, Vol. 46, No. 5: 1665-1691.

Butler, Alexander W., Gustavo Grullon, dan James P. Weston. 2005. Stock Market Liquidity and the Cost of Issuing Equity. Journal of Financial and Quantitative Analysis, Vol. 40, No. 2: 331-348.

Chen, Yangyang, Huu Nhan Duong, dan S. Ghon Ree. 2012. Stock Liquidity and the Value of Cash Holdings. Unpublished Working Paper. Monash University, Australia.

Denis, David J. dan Valeriy Sibilkov. 2010. Financial Constraints, Investment, and the Value of Cash Holdings. Review of Financial Studies, Vol. 23, No. 1: 247269. 
Fang, Vivian W., Thomas Noe, dan Sheri Tice. 2009. Stock Market Liquidity and Firm Value. Journal of Financial Economics, Vol. 94, No. 1: 150-169.

Faulkender, Michael dan Rong Wang. 2006. Corporate Financial Policy and the Value of Cash. Journal of Finance, Vol. 61, No. 4: 1957-1990.

Ferreira, Miguel A. dan Antonio S. Vilela. 2004. Why Do Firms Hold Cash? Evidence from EMU Countries. European Financial Management, Vol. 10, No. 2: 295319.

Gill, Amarjit, Charul Shah. 2012. Determinants of Corporate Cash Holdings: Evidence from Canada. International Journal of Economics and Finance, Vol. 4, No. 1: 70-79.

Jensen, Michael C. 1986. Agency Costs of Free Cash Flow, Corporate Finance and Takeovers. American Economic Review, Vol 76, No. 2:323-329.

Khanna, Naveen dan Ramana Sonti. 2004. Value Creating Stock Manipulation: Feedback Effect of Stock Prices on Firm Value. Journal of Financial Markets, Vol. 7, No. 3:237-270.

Myers, Stewart C. 1984. The Capital Structure Puzzle. Journal of Finance, Vol. 39, No. 3: 574-592.

Myers, Stewart C. dan Majluf Nicholas S. 1984. Corporate Financing and Investment Decisions When Firms Have Information that Investors Do Not Have. Journal of Financial Economics, Vol. 13, No. 2: 187-221.

Nachrowi, Nachrowi Djalal dan Hardius Usman. 2006. Pendekatan Populer dan Praktis Ekonometrika untuk Analisis Ekonomi dan Keungan. Jakarta: LPFEUniversitas Indonesia. 
Nyborg, Kjell G. dan Zexy Wang. 2014. Stock Liquidity and Corporate Cash Holdings: Feedback and the Cash as Ammunition Hypothesis. Unpublished Working Paper. Swiss Finance Institute.

Opler, Tim, Lee Pinkowitz, René Stulz, Rohan Williamson. 1999. The Determinants and Implications of Corporate Cash Holdings. Journal of Financial Economics, Vol. 52, No. 1: 3-46.

Subrahmanyam, Avanidhar dan Sheridan Titman. 2001. Feedback from Stock Prices to Cash Flows. Journal of Finance, Vol. 56, No. 6: 2389-2413.

Sutrisno, Bambang dan Tatang Ary Gumanti. 2016. Pengaruh Krisis Keuangan Global dan Karakteristik Perusahaan terhadap Cash Holding Perusahaan di Indonesia. Jurnal Siasat Bisnis, Vol. 20, No. 2: 130-142.

Sutrisno, Bambang. 2017. Hubungan Cash Holding dan Nilai Perusahaan di Indonesia. Jurnal Dinamika Akuntansi dan Bisnis, Vol. 4, No. 1: 45-56.

Tehrani, Reza, Roya Darabi, dan Sara izy. 2014. The Relation between Stock Liquidity \& Cash Holdings in Tehran Stock Exchange. International Journal of Business and Social Science, Vol. 5, No. 2: 277-284.

Titman, Sheridan dan Roberto Wessels. 1988. The Determinants of Capital Structure Choice. Journal of Finance, Vol. 43, No. 1, 1-19.

Wiyono, Gendro dan Hadri Kusuma. 2017. Manajemen Keuangan Lanjutan Berbasis Corporate Value Creation. Yogyakarta: UPP STIM YKPN. 